\title{
Matrix metalloproteinases 2 and 9 expression in canine normal prostate and with proliferative disorders
}

\author{
Expressão de metaloproteinases de matriz 2 e 9 na próstata canina normal e com lesões \\ proliferativas
}

\author{
Mariana Batista Rodrigues Faleiro ${ }^{I^{*}}$ Giuliana Brasil Croce $^{\mathrm{II}}$ Denise Caroline Toledo \\ Marcela Marcondes Pinto Rodrigues ${ }^{\text {II }}$ Aline Carvalho Batista ${ }^{\text {III }}$ Adilson Donizeti Damasceno ${ }^{\text {IV }}$ \\ Luiz Augusto Batista Britov ${ }^{v}$ Renée Laufer Amorim ${ }^{\text {II }}$ \\ Veridiana Maria Brianezi Dignani de Mourav
}

\begin{abstract}
In this study the expression of metalloproteinases 2 $(M M P-2)$ and 9 (MMP-9) in canine normal prostates and with proliferative disorders was evaluated to verify the role of these enzymes in extracellular matrix remodeling (ECM) and in the tissue invasion process. A total of 355 prostatic samples were obtained, from which 36 (10.1\%) were normal prostates, 46 (13.0\%) with benign prostatic hyperplasia (BPH), 128 (36.1\%) with proliferative inflammatory atrophy (PIA), 74 (20.8\%) with prostatic intraepithelial neoplasia (PIN), and 71 (20.0\%) with prostatic carcinoma $(P C)$. Difference in cytoplasmic immunohistochemical staining of MMP-2 and MMP-9 between acinar epithelium and periacinar stroma was found regarding the different diagnosis. The correlation between MMP-2 and MMP-9 expression in relation to the number of labeled cells in acinar epithelium and periacinar stroma, as well as to the staining intensity in the periacinar stromal cells was evidenced in canine prostates with PIA. In conclusion, MMP-2 and MMP9 expression has a variation in canine prostate according to the lesion, with lower expression in normal tissue and with $B P H$, and higher expression in those with PIA, PIN and PC. Moreover, the inflammatory microenvironment of the PIA has influence in the activity of both enzymes.
\end{abstract}

Key words: dog, gelatinases, benign prostatic hyperplasia, proliferative inflammatory atrophy, prostatic intraepithelial neoplasia, prostatic carcinoma.

\section{RESUMO}

Este estudo teve como objetivo avaliar a expressão das metaloproteinases 2 (MMP-2) e 9 (MMP-9) em próstatas caninas normais e com desordens proliferativas, verificando o papel dessas enzimas na remodelação da matriz extracelular (MEC) e no processo de invasão tecidual. Um total de 355 amostras prostáticas foram obtidas, sendo $36(10,1 \%)$ normais, 46 (13,0\%) com hiperplasia prostática benigna (HPB), 128 $(36,1 \%)$ com atrofia inflamatória proliferativa (PIA), 74 (20,8\%) com neoplasia intraepitelial prostática (PIN) e 71 (20,0\%) com carcinoma prostático $(C P)$. Houve diferença de imunomarcação citoplasmática para MMP-2 e MMP-9 entre o epitélio acinar e o estroma periacinar, quanto aos diferentes diagnósticos. Observou-se correlação entre a expressão de MMP-2 e MMP-9 em relação ao número de células marcadas no epitélio acinar e estroma periacinar, bem como para a intensidade de marcação das células estromais periacinares em próstatas caninas com PIA. Conclui-se que há variação na expressão de MMP-2 e MMP-9 em próstatas caninas de acordo com a lesão, com menor expressão em próstatas caninas normais e com HPB, e maior naquelas com PIA, PIN e CP. Ainda, o microambiente inflamatório na PIA influencia a atividade de ambas as enzimas.

Palavras-chave: cão, gelatinases, hiperplasia prostática benigna, atrofia inflamatória proliferativa, neoplasia intraepitelial prostática, carcinoma prostático.

\section{INTRODUCTION}

The canine prostate have been studied due to its similarities to the human prostate regarding the natural occurrence of diseases and the hormonal

'Programa de Pós-graduação em Ciência Animal, Área de Patologia, Clínica e Cirurgia Animal, Escola de Veterinária e Zootecnia (EVZ), Universidade Federal de Goiás (UFG), Campus II, Rodovia Goiânia-Nova Veneza, 74001-970, CP 131, Goiânia, GO, Brasil. E-mail: marianafavet@hotmail.com.*Autor para correspondência.

"Serviço de Patologia Veterinária, Departamento de Clínica Veterinária, Faculdade de Medicina Veterinária e Zootecnia (FMVZ), Universidade Estadual Paulista (UNESP), Botucatu, SP, Brasil.

II'Departamento de Ciências Estomatológicas, Faculdade de Odontologia, UFG, Goiânia, GO, Brasil.

IV Setor de Clínica Veterinária, Departamento de Medicina Veterinária, EVZ, UFG, Goiânia, GO, Brasil.

${ }^{{ }^{V} S e t o r ~ d e ~ P a t o l o g i a ~ A n i m a l, ~ D e p a r t a m e n t o ~ d e ~ M e d i c i n a ~ V e t e r i n a ́ r i a, ~ E V Z, ~ U F G, ~ G o i a ̂ n i a, ~ G O, ~ B r a s i l . ~}$ 
influence in their development, for instance, benign prostatic hyperplasia (BPH) and prostatic carcinoma (PC) (LEROY \& NORTHRUP, 2009). Some dysplastic lesions of man's prostate are considered premalignant, as the prostatic intraepithelial neoplasia (PIN), because they show morphological similarities to cancer or involve potentially carcinogenic factors (DE MARZO et al., 2006). The proliferative inflammatory atrophy (PIA) is another lesion that has been investigated to determine its premalignant potential (WANG et al., 2009).

In dogs, PIN has been considered a premalignant lesion and can be observed in cases of PC (WATERS et al., 1997; MADEWELL et al., 2004; MATSUZAKI et al., 2010). Also, RODRIGUES et al. (2010) mentioned PIA in canine prostate and TOLEDO et al. (2010) described it histological aspects in the gland of dogs.

The tumor invasion processes involves hydrolytic destruction of extracellular matrix (ECM) components by proteolytic enzymes and migration of neoplastic cells through the altered extracellular environment (AMBIRU et al., 1997). The matrix metalloproteinases (MMP) are proteolytic enzymes involved in tumor invasion (QUARANTA, 2000) and the expression of MMP-2 (gelatinase A) and MMP-9 (gelatinase B) has been studied in benign and malignant human prostatic tumors (WILSON et al., 2002).

LOUKOPOULOS et al. (2003)

demonstrated for the first time the involvement of MMP-2 and MMP-9 in canine tumors as well as the relation of such proteins with the different tumoral levels. Previous studies have demonstrated the presence of these proteins in canine tumors and normal tissues, being detected in higher levels in dogs with osteosarcoma (LANA et al., 2000) and cutaneous mast cell tumors (LEIBMAN et al., 2000) than in unaffected stromal tissues. Nevertheless, reports relative to the involvement of MMP in benign and malignant tumors of the canine prostate have not been located.

In this study the expression of MMP-2 and MMP-9 in both normal canine prostatic tissue and with proliferative disorders, including $\mathrm{BPH}$, PIN, PIA and PC, was verified to evaluate the role of these enzymes in ECM remodeling and in the tissue invasion process.

\section{MATERIALS AND METHODS}

The evaluated samples were derived from archives of two Veterinary Pathology Laboratories. Three- $\mu \mathrm{m}$-sections were obtained from formalin- fixed-paraffin-embedded (FFPE) tissue blocks and stained with hematoxylin and eosin (HE) for microscopic examination. Histomorphological evaluation included normal prostates and with BHP (LEAV et at., 2001), PIA (TOLEDO et al., 2010), PIN (BOSTWICK 1995), and PC (VASTO, 2008). All histological slides were examined by three investigators. All prostatic samples were from adult dogs and normal prostatic tissues were from dogs with no lesions in the gland.

The prostate tissue microarray (TMA) was carried out according to criteria described by KONONEN et al. (1998) and BUBENDORF et al. (2001). From the previous defined areas in histomorphological evaluation, tissue cores with a dimension of $1.0 \mathrm{~mm}$ were taken from FFPE tissue samples and arrayed on a recipient paraffin block using the Tissue Microarrayer (Beencher Instruments $^{\circledR}$, Silver Spring, USA). Three- $\mu$ msections were obtained of the recipient block and distended on silanized slides for HE staining and immunohistochemistry.

Immunohistochemistry was performed in two TMA slides, which were deparaffinized, rehydratated and washed in distilled water. For antiMMP-2 mouse monoclonal antibody, clone A-Gel VC2 (DBS - Mob 312), was used 1:25 dilution and antigen retrieval, in water bath at $96^{\circ} \mathrm{C}$, for $30 \mathrm{~min}$, with $10 \mathrm{mM}$ of pre-heated citrate buffer, $\mathrm{pH}$ 6.0. For anti-MMP-9 rabbit polyclonal antibody (Dako A0150), was used 1:200 dilution and antigen retrieval in water bath at $96^{\circ} \mathrm{C}$, for $20 \mathrm{~min}$, with pre-heated TRIS-EDTA buffer, $\mathrm{pH}$ 9.0. Endogenous peroxidase activity was blocked and incubation with both primary antibodies was carried out in a wet chamber, at $4^{\circ} \mathrm{C}$, for $18 \mathrm{~h}$. Advance HRP signal amplification system (Dako K 4068) was used and the reaction was visualized by the use of DAB (Diaminobenzidine, Dako, K3468-1). Sections were counterstained with Mayer's hematoxylin, washed, dehydrated, cleared, mounted, and examined by light microscopy.

Human placenta was used as the positive tissue control for both MMP-2 and MMP-9. The primary antibody was replaced by TRIS buffer, $\mathrm{pH}$ 7.4 , on canine prostate for the negative antibody control. The intensity of cytoplasmic reactivity of the antibodies within acinar epithelium and periacinar stromal cells was subjectively scored as: $0=$ negative, $1=$ discrete, $2=$ moderate and $3=$ intense. Regarding the number of both acinar epithelium and periacinar stromal stained cells, the scores were: $0=$ negative, $1=1-25 \%, 2=26-50 \%, 3=51-75 \%$ and $4=76-100 \%$. 
Kruskal-Wallis and Mann Whitney tests as well as descriptive data were used to compare the scores of percentage of positive cells and their intensity. Association between MMP2, MMP9 expression in normal prostatic tissue and with the different lesions studied was achieved by Spearman test. All values were considered with $5 \%$ of significance level.

\section{RESULTS}

From the TMA 355 diagnoses were obtained, from which $36(10.1 \%)$ were normal tissues, 46 (13.0\%) BPH, 128 (36.1\%) PIA, 74 (20.8\%) PIN, and $71(20.0 \%)$ PC. Concerning PIA $(n=128)$, it was observed that $71(55.5 \%)$ were discrete (PIA-D), 39 (30.5\%) moderate (PIA-M) and 18 (14.0\%) intense (PIA-I).

Immunohistochemistry staining for MMP2 and MMP-9 was cytoplasmic (Figure 1). Acinar and periacinar MMP-2 expression in normal prostatic tissue was different from those with BPH, PIA,
PIN and PC, as well as it was different in prostatic tissues with BPH from those with PIA, PIN and PC, regarding the number and intensity of positive cells $(\mathrm{P}<0.05)$. MMP-9 expression showed difference between normal from PIA, PIN and PC tissues for the same variants $(\mathrm{P}<0.05)$. Also, there was a difference to MMP-9 regarding number and intensity of stained periacinar cells between normal and BPH tissue $(\mathrm{P}<0.05)$. A difference in the number of stained acinar cells to MMP-9 was observed between BPH and PIA, PIN and CP tissues $(\mathrm{P}<0.05)$. Still about MMP-9, there was a difference in the intensity staining of acinar cells between $\mathrm{BPH}$ and $\mathrm{PC}$ as well as between $\mathrm{PIN}$ and $\mathrm{PC}$ tissues $(\mathrm{P}<0.05)$.

Regarding the types of PIA, there was a significant difference in the number of stained cells and the intensity of staining of periacinar cells between PIA-D and PIA-M, as well as in the number of stained periacinar cells between PIA-D and PIA-I $(\mathrm{P}<0.05)$ to MMP-9, but no significant difference to MMP-2 was observed (Table 1).

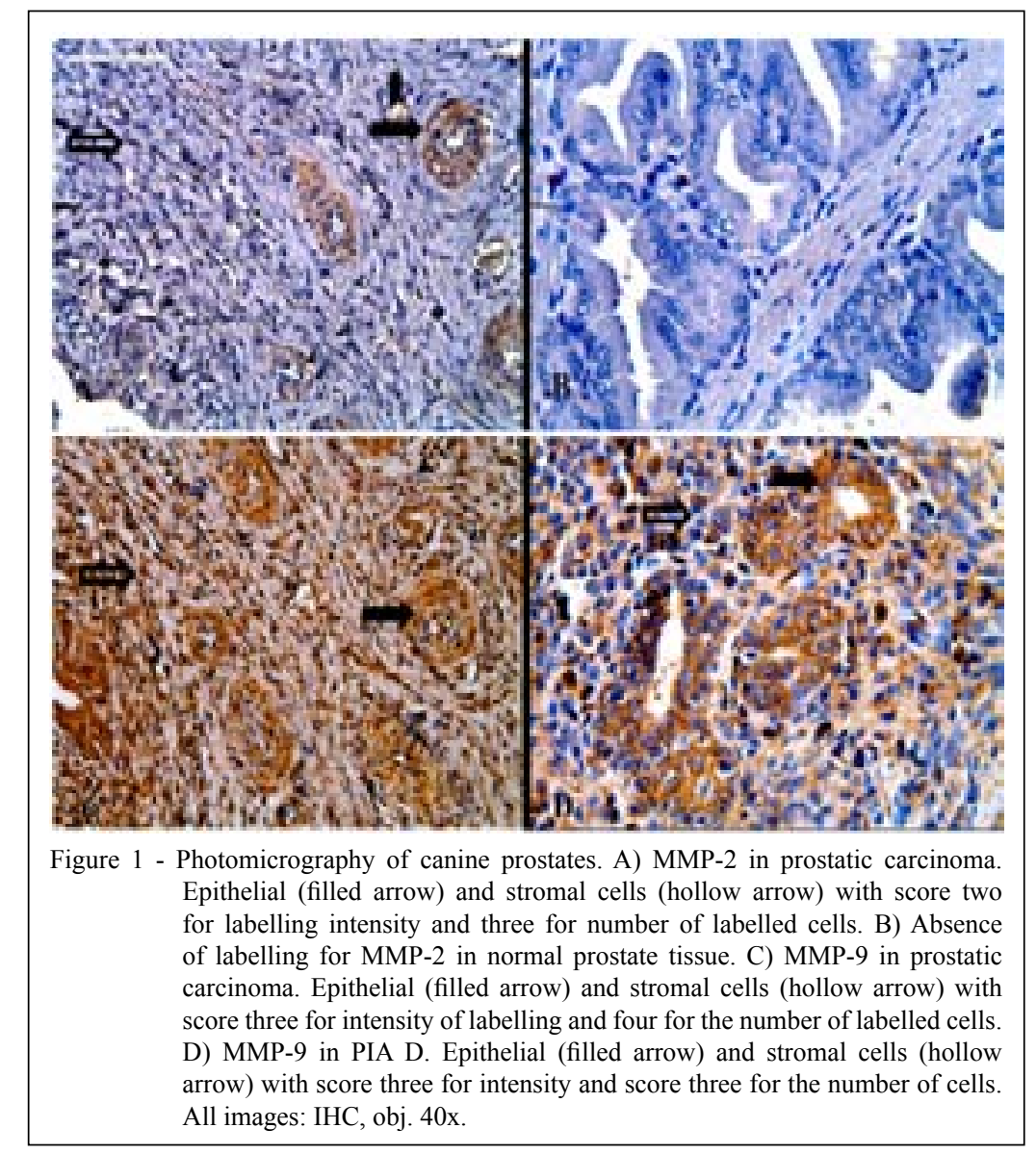

Ciência Rural, v.43, n.6, jun, 2013. 
Table 1 - Means of comparison among diagnoses and of correlation between MMP-2 and MMP-9 expression regarding the number of stained cells and intensity of staining in epithelial and stromal cells of the normal canine prostate and with BPH, PIA, PIN and PC.

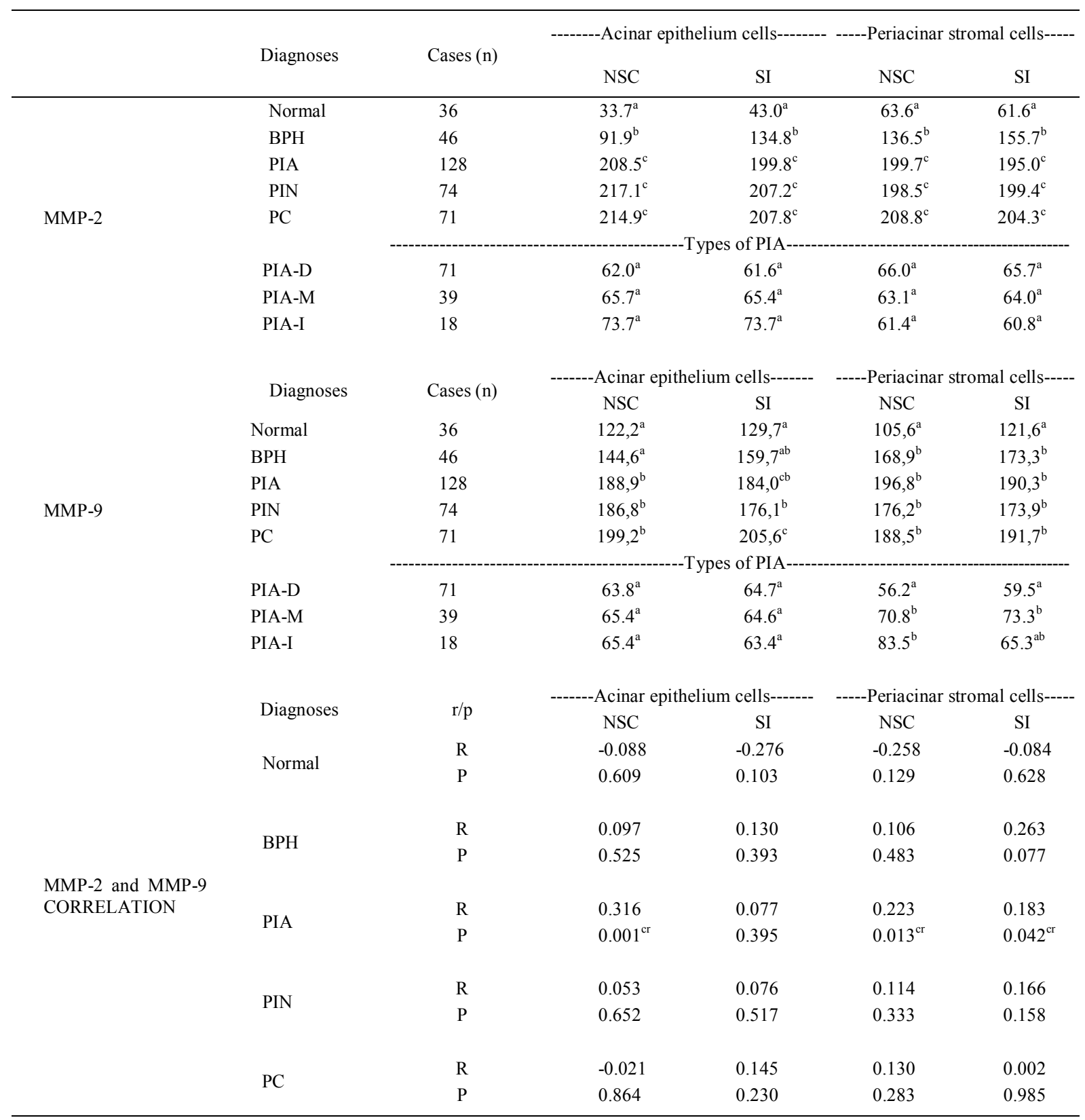

Similar letters in the same column are not different by the U-Mann-Whitney test $(\mathrm{P}>0.05)$. NSC - number of stained cells; SI- staining intensity; $r$ = Spearman's correlation between MMP-2 and MMP-9; P values followed by the letters cr represents the correlation between MMP2 and MMP9 $(\mathrm{P}<0.05)$.

There was correlation among the number of stained cells in acinar epithelium, number of stained cells in the periacinar and intensity of staining of periacinar cells between MMP-2 and MMP-9 antibodies only in canine prostates with PIA $(\mathrm{P}<0.05)$ (Table 1).

\section{DISCUSSION}

LANA et al. (2000), BREHMER et al. (2003), LOUKOPOULOS et al. (2003), DELELLA et al. (2010) have studied gelatinases MMP-2 and MMP9 in both normal tissues and the ones with benign 
and malignant lesions in different species, including dogs, since MMPs are proteolytic enzymes capable of degrading components of connective tissue, such as the ECM, during tissue remodeling, which occurs in physiologic and pathologic conditions (EGEBLAD \& WERB, 2002; MOOK et al., 2004). However, no previous MMP evaluation of metalloproteinases in normal canine prostate and with benign, dysplastic and malignant lesions has been carried out, as it was done in this study.

According to APARICIO et al. (1999), MMP expression occurs in tumor cells and stromal cells adjacent to the invasive tumor, providing an efficient mechanism for the degradation of ECM. It is likely that both cellular components contribute in different ways to the metastatic cascade (APARICIO et al., 1999). Moreover, MMP-positive tumor cells can contribute to tumor growth and invasion, while the stromal component collaborates with the remodeling process that occurs in the tumoral neighboring tissue.

In this study, MMP-2 and MMP-9 protein expression was observed in both epithelial and stromal cells in canine prostatic tissue, regardless of the histomorphological condition, as it occurs in human (BREHMER et al., 2003) and rats prostates (DELELLA et al., 2010). LANA et al. (2000), LEIBMAN et al. (2000), LOUKOPOULOS et al. (2003), KAWAI et al. (2006) and VINOTHINI et al. (2009) evaluated MMP-2 and 9 protein expression in non-prostatic neoplastic canine tissues, and reported higher immune staining of these enzymes in tumor cells than in adjacent stromal cells, as it was observed in the prostatic tumors in this study.

The difference observed regarding the comparison of positive and intensity of MMP-2 and MMP-9 stained cells in acinar epithelial cells and stromal periacinar cells, related to the different lesions studied, indicated that these enzymes exhibit variable expression in canine prostate tissue according to the lesion. There was higher expression of epithelial and stromal MMP-2 in glands with PIA, $\mathrm{PIN}$ and PC in comparison to normal glands and with BPH. In the same manner, BREHMER et al. (2003), ZHONG et al. (2008) and ESCAFF et al. (2011) observed higher expression of MMP-2 and MMP9 in neoplastic human prostate than in normal ones or with BPH, respectively. Besides, ESCAFF et al. (2010) found higher expression of different types of MMP and TIMP in human prostates with carcinoma than in glands with benign changes, concluding that such enzymes have an important role in the molecular biology of prostatic carcinomas.

The comparison of the MMP-2 expression between premalignant lesions (PIA and PIN) and
PC, as well as among the types of PIA did not show immunostaining variation, since it was high in all of them. In humans, malignant tissues exhibit overexpression of MMP and underexpression of its inhibitors (TIMP), resulting in increased proteolytic activity (BÖHLER \& KALTHOFF, 1999; JOHNSEN et al., 1998), which expands the capacity of cell invasion across the ECM and dissemination of the neoplasia (MCCAWLY \& MATRISIAN, 2001).

MMPoverexpression is mediated by growth factors and cytokines secreted by neoplasic, stromal and inflammatory cells (BÖHLER \& KALTHOFF, 1999). Thus, it is likely that the increased expression of MMP-2 and MMP-9 in canine PIA is mediated by inflammatory cells located in the periacinar stroma, intensifying the premalignant potential of the lesion, considering that in higher MMP concentration there is higher ECM lysis activity. Therefore, both dysplastic epithelial cells of PIA and inflammatory cells in the stroma can be involved in neoplastic transformation and tumor invasion. MOOK et al. (2004) also suggested that the increase of MMP-9 expression in tumors surrounded by inflammation results in local proteolysis and contributes to tumor invasion.

As was observed for MMP-2, the expression of MMP-9 in canine prostates is higher in tissues with premalignant lesions and PC than in normal tissues and the ones with BPH. Furthermore, the intensity of MMP-9 staining in carcinoma epithelial cells was higher than in PIN, suggesting increased proteolytic activity and consequently greater potential for invasion of the malignant canine prostate tissue than the premalignant tissue without neighboring inflammation. This hypothesis is based on the reports that MMP-9 is expressed mainly by malignant cells (MASSOVA et al., 1998; NAGAOKA \& HIROTA, 2000).

Moreover, as there was no difference in the variables of MMP-9 expression between PIA and $\mathrm{PC}$, it can be concluded that these lesions have the same expression profile for MMP-9, and probably carcinoma cells are responsible for the increase of MMP-9 expression as described by ZHONG et al. (2008), whereas in PIA this increase appears to be related to inflammatory cells found within the stroma. The higher stromal expression of MMP-9 in both moderate and intense PIA supports this idea.

MMP-2 and MMP-9 correlation was found in prostates with PIA. In other words, in the inflammatory microenvironment, MMP-2 and MMP9 showed concomitant and equivalent expression increase, particularly in stromal cells, suggesting initially higher ECM proteolysis potential making

Ciência Rural, v.43, n.6, jun, 2013. 
easier the invasion of malignant glandular epithelial cells. However, this is just a possibility, considering that the expression of metalloproteinase inhibitors (TIMP) was not evaluated. According to BREHMER et al. (2003), the balanced activity of MMP and TIMP is the main responsible factor for the ECM proteolytic degradation control, while the imbalance of these enzymes contributes to tumor progression (LICHTINGHAGEN et al., 2002). Besides, other proteins may be involved in this cascade, which results in degradation of biological barriers, such as TGF- $\beta$ that regulates the expression of MMP-2 and MMP-9 in prostate tissue (WILSON et al., 2002). It means that there is an increase of these enzymes in the presence of TGF- $\beta$, which may explain MMP higher expression in canine prostates with PIA (RODRIGUES et al., 2010).

\section{CONCLUSION}

There is variation in the expression of MMP-2 and MMP-9 in canine prostate according to the lesion. The lower expression in normal prostates and with BHP indicates the involvement of these enzymes in ECM remodeling while the higher expression in prostates with premalignant and malignant lesions suggests the action of these in the tissue invasion process. More, the inflammation (PIA) increases simultaneously the activity of both enzymes.

\section{REFERENCES}

AMBIRU, S., et al. A prospective study of prognostic value of type IV collagenase activity in colorectal cancer tissue. Digestive Disease and Sciences, v.42, n.8, p.1660-1665, 1997. Available from: $<$ http://www.springerlink.com/content/x6550164543u1k02/>. Accessed: may 20, 2010. DOI: 10.1023/A:1018801229372.

APARICIO, T., et al. Matrix metalloproteinase inhibition prevents colon cancer peritoneal carcinomatosis development and prolongs survival in rats. Carcinogenesis, v.20, n.4, p.14451452, 1999. Available from: <http://carcin.oxfordjournals.org/ content/20/8/1445.full.pdf + html $>$. Accessed May 20, 2010. doi: $10.1093 /$ carcin/20.8.1445.

BÖHLE, A.S., KALTHOFF, H. Molecular mechanisms of tumor metastasis and angiogenesis. Langenbecks Archives Surgery, v.384, n.2, p.133-140, 1999. Available from: <http://www. springerlink.com/content/pnlgq8gkv52pn73g/>. Accessed may 20, 2010. DOI: $10.1007 / \mathrm{s} 004230050183$.

BOSTWICK, D.G. High-grade prostatic intraepithelial neoplasia: the most likely precursor of prostate cancer. Cancer, v.75, n.7, p.1823-1836, 1995. Available from: <http://onlinelibrary.wiley. com/doi/10.1002/1097-0142\%2819950401\%2975:7\%2B\%3C18 23::AID-CNCR2820751612\%3E3.0.CO;2-7/pdf $>$. Accessed may 20, 2010. DOI: 10.1002/1097-0142(19950401)75:7+<1823::AIDCNCR2820751612>3.0.CO;2-7.
BREHMER, B., et al. Expression of matrix metalloproteinases (MMP-2 and-9) and their inhibitors (TIMP-1 and -2) in prostate cancer tissue. Prostate Cancer Prostatic Disease, v.6, p.217222, 2003. Available from: <http://www.nature.com/pcan/journal/ v6/n3/pdf/4500657a.pdf $>$. Accessed may 20, 2010. doi:10.1038/ sj.pcan. 4500657 .

BUBENDORF, L, et al. Tissue microarray (TMA) technology: miniaturized pathology archives for high-throughput in situ studies. Journal of Pathology, v.195, n.1, p.72-79, 2001. Available from: <http://onlinelibrary.wiley.com/doi/10.1002/path.893/pdf>. Accessed may 20, 2010. DOI: 10.1002/path.893.

DE MARZO, A.M., et al. A working group classification of focal prostate atrophy lesions. American Journal of Surgical Pathology, v.30, n.10, p.1281-1291, 2006. Available from: <http:// journals.lww.com/ajsp/pages/articleviewer.aspx?year=2006\&issue= $10000 \&$ article $=00011 \&$ type $=$ abstract $>$. Accessed may 25, 2010 . doi: 10.1097/01.pas.0000213289.50660.be.

DELELLA, F.K., et al. Finasteride treatment alters MMP-2 and -9 gene expression and activity in the rat ventral prostate. International Journal of Andrology, v.33, n. 1, p.114-122, 2010. Available from: <http://onlinelibrary.wiley.com/doi/10.1111/ j.1365-2605.2009.00970.x/pdf $>$. Accessed may 20, 2011. DOI:10.1111/j.1365-2605.2009.00970.x.

EGEBLAD, M.; WERB, Z. New functions for the matrix metalloproteinases in cancer progression. Nature Reviews Cancer, v.2, n.1, p.161-174, March 2002. Available from: $<$ http:// www.nature.com/nrc/journal/v2/n3/pdf/nrc745.pdf $>$. Accessed May 02, 2010. DOI:10.1038/nrc745.

ESCAFF, S., et al. Comparative study of stromal metalloproteases expression in patients with benign hyperplasia and prostate cancer. Journal of Cancer Research and Clinical Oncology, v. 137, n. 3, p.551-555, 2011; Available from: <http://www.springerlink. com/content/b638211p82781313/>. Accessed may 15, 2012. DOI 10.1007/s00432-010-0906-8.

ESCAFF, S., et al. Study of matrix metalloproteinases and their inhibitors in prostate cancer. British Journal of Cancer, v.102, n. 1, p.922-929, 2010. Available from: < http://www.nature.com/ bjc/journal/v102/n5/pdf/6605569a.pdf>. Accessed may 15, 2011. doi:10.1038/sj.bjc.6605569.

JOHNSEN, M. et al. Cancer invasion and tissue remodeling: common Themes in proteolytic matrix degradation. Current Opinion in Cell Biology, v.10, n.1, p.667-671, 1998. Available from: <http:// www.sciencedirect.com/science/article/pii/S0955067498800446>. Accessed May 02, 2010. DOI: 10.1016/S0955-0674(98)80044-6.

KAWAI, K., et al. The activity of matrix metalloproteinases (MMPs) and tissue inhibitors of metalloproteinases (TIMPs) in mammary tumors of dogs and rats. Journal of Veterinary. Medical Science, v. 68, n. 1, p.105-111, 2006. Available from: $<$ https://www.jstage.jst.go.jp/article/jvms/68/2/68_2_105/_pdf $>$. Accessed may 22, 2010. Doi:10.1292/jvms.68.105.

KONONEN, J., et al. Tissue microarrays for high-throughput molecular profiling tumor of specimens. Nature Medicine, v.4, n. 7, p.844-847, 1998. Available from: <http://www.nature.com/ nm/journal/v4/n7/pdf/nm0798-844.pdf >. Accessed may 20, 2010. doi:10.1038/nm0798-844.

LANA, S.E. et al. Identification of matrix metalloproteinases in canine neoplastic tissue. American Journal of Veterinary 
Research, v.61, n.2, p.111-114, 2000. Available from: <http:// avmajournals.avma.org/doi/abs/10.2460/ajvr.2000.61.111>. Accessed may 20, 2012. DOI:10.2460/ajvr.2000.61.111.

LEAV, I. et al. Role of canine basal cells in postnatal prostatic development, induction of hyperplasia, and sex hormonestimulated growth, and the ductal origin carcinoma. The Prostate, v.47, n.1, p.149-163, 2001. Available from: <http://onlinelibrary. wiley.com/doi/10.1002/pros.1100/pdf>. Accessed may 21, 2012 DOI:10.1002/pros. 1100 .

LEIBMAN, N.F. et al. Identification of matrix metalloproteinases in canine cutaneous mast cell tumors. Journal of Veterinary Internal Medicine, v.14, n.6, p.583-586, Nov 2000. Available from: $<\mathrm{http}$ :/ onlinelibrary.wiley.com/doi/10.1111/j.1939-1676.2000.tb02280.x pdf $>$. Accessed Jun 10, 2010. DOI:10.1111/j.1939-1676.2000. tb02280.x.

LEROY, B.E.; NORTHRUP, N. Prostate cancer in dogs: Comparative and clinical aspects. The Veterinary Journal, v.180, n.2, p.149-162, 2009. Available from: <http://www.sciencedirect. com/science/article/pii/S1090023308002670>. Accessed may 20, 2010. DOI: 10.1016/j.tvj1.2008.07.012.

LICHTINGHAGEN, R. et al. Different mRNA and protein expression of matrix metalloproteinases 2 and 9 and tissue inhibitor of metalloproteinases 1 in benign and malignant prostate tissue. European Urology, v.42, n.4, p.398-406, 2002. Available from: $<$ http://www.sciencedirect.com/science/article/pii/ S030228380200324X>. Accessed may 20, 2010. DOI: 10.1016/ S0302-2838(02)00324-X.

LOUKOPOULOS, P. et al. Matrix metalloproteinase-2 and -9 involvement in canine tumors. Veterinary Pathology, v.40, n.4, p.382-394, 2003. Available from: <http://vet.sagepub.com/ content/40/4/382.full.pdf + html $>$. Accessed may 20, 2012. DOI: $10.1354 /$ vp.40-4-382.

MADEWELL, B.R. et al. Canine prostatic intraepithelial neoplasia: Is the comparative model relevant? The Prostate, v.58, n.1, p.314-317, 2004. Available from: <http://onlinelibrary.wiley. com/doi/10.1002/pros.10338/pdf $>$. Accessed may 20, 2010. DOI: $10.1002 /$ pros. 10338

MASSOVA, I. et al. Matrix metalloproteinases: structures, evolution, and diversification. The Journal of the federation of American societies for experimental Biology, v.12, n.12, p.1075-1095, 1998. Available from: <http://www.fasebj.org/ content/12/12/1075.full.pdf + html $>$. Accessed may 22, 2010. DOI: 0892-6638/98/0012-1075.

MATSUZAKI, P. et al. Immunohistochemical characterization of canine prostatic intraepithelial neoplasia. Journal of Comparative Pathology, v.142, n.1, p.84-88, 2010. Available from: <http:// www.sciencedirect.com/science/article/pii/S0021997509000929>. Accessed may 20, 2011. DOI: 10.1016/j.jcpa.2009.06.005.

MCCAWLEY, L.J.; MATRISIAN, L.M. Matrix metaloproteinases: they're not just for matrix anymore. Current Opinion in Cell Biology, v.13, n.5, p.534-540, 2001. Available from: <http:// www.sciencedirect.com/science/article/pii/S0955067400002489>. Accessed may 20, 2010. DOI: 10.1016/S0955-0674(00)00248-9.

MOOK, O.R.F. et.al. The role of gelatinases in colorectal cancer progression and metastasis. Biochimica et Biophysica Acta-Reviews on Cancer, v.1705, n.2, p.69-89, 2004. Available from: <http://
www.sciencedirect.com/science/article/pii/S0304419X04000629>. Accessed may 20, 2010. DOI: 10.1016/j.bbcan.2004.09.006.

NAGAOKA, I.; HIROTA, S. Increased expression of matrix metalloproteinase-9 in neutrophils in glycogen-induced peritoneal inflammation of guinea pigs. Inflammation Research, v.49, n.2, p.55-62, 2000. Available from: <http://link.springer.com/article/ 10.1007\%2Fs000110050559? LI =true $>$. Accessed may 21, 2010. DOI: $10.1007 / \mathrm{s} 000110050559$.

QUARANTA V. Cell migration through extracellular matrix: membrane-type metalloproteinases make the way. Journal of Cell Biology, v.149, n.6, p.1167-1169, 2000. Available from: <http:// jcb.rupress.org/content/149/6/1167.full>. Accessed Jun 05, 2010. DOI: $10.1083 /$ jcb.149.6.1167.

RODRIGUES, M.M.P. etal.COX- 2 and TGF- $\beta$ expression in proliferative disorders of canine prostate. Brazilian Journal of Veterinary Pathology, v.3, n.1, p.31-36, 2010. Available from: <http://www.abpv.vet.br/upload/ documentos/V.3,-N.1,-06-20881 201042935 14.pdf>. Accessed may 15, 2011. DOI: $201033176 \overline{2} 2$

TOLEDO, D.C., et al. Histomorphological characterization of proliferative inflammatory atrophy in canine prostate. Ciência Rural, v.40, n.6, p.1372-1377, 2010. Available from: $<$ http://www. scielo.br/pdf/cr/v40n6/a629cr2548.pdf>. Accessed may 15, 2011. Doi.10.1590/S0103-84782010000600021.

VASTO, $\mathrm{S}$ et al. Inflammation and prostate cancer. Future Oncology, v. 4, n. 5, 2008, p.637-645 Available from: <http:// www.futuremedicine.com/doi/full/10.2217/14796694.4.5.637>. Accessed may 15, 2011 doi: 10.2217/14796694.4.5.637.

VINOTHINI, G., et al. Evaluation of Molecular Markers in Canine Mammary Tumors: Correlation With Histological Grading. Oncology Research, v.18, n.5, p.193-201, 2009. Available from: <http://dx.doi. org/10.3727/096504009X12596189659042>. Accessed may 20, 2010. DOI: $10.3727 / 096504009 X 12596189659042$.

WANG, W., et al. Morphological Transition of Proliferative Inflammatory Atrophy to High-Grade Intraepithelial Neoplasia and Cancer in Human Prostate. The Prostate, v.69, n.13, p.1378-1386, 2009. Available from: <http://onlinelibrary.wiley. com/doi/10.1002/pros.20992/pdf>. Accessed may 20, 2010 DOI:10.1002/pros.20992.

WATERS, D.J., et al. Prostatic intraepithelial neoplasia in dogs with spontaneous prostate cancer. Prostate, v.30, n.1, p.9297, 1997. Available from: <http://onlinelibrary.wiley.com/do i/10.1002/\%28SICI\%291097-0045\%2819970201\%2930:2\% 3C92::AID-PROS4\%3E3.0.CO;2-M/pdf $>$. Accessed may 20, 2010. DOI:10.1002/(SICI)1097-0045(19970201)30:2<92::AIDPROS4>3.0.CO;2-M

WILSON, M.J., et al. Expression of matrix metalloproteinase-2 and -9 and their inhibitors, tissue inhibitor of metalloproteinase- 1 and -2 , in primary cultures of human prostatic stromal and epithelial cells. Journal of Cellular Physiology, v.191, n.5, p.208-216, 2002. Available from: $<$ http://onlinelibrary.wiley.com/doi/10.1002/ jcp.10092/pdf $>$. Accessed may 20, 2010. DOI:10.1002/jcp.10092.

ZHONG, W., et al. CD147, MMP-1, MMP-2 and MMP-9 protein expression as significant prognostic factors in human prostate cancer. Oncology, v.75, n.1, p.230-236, 2008. Available from: <http:// content.karger.com/produktedb/produkte.asp?doi $=163852>$. Accessed may 20, 2010. DOI: 10.1159/000163852. 